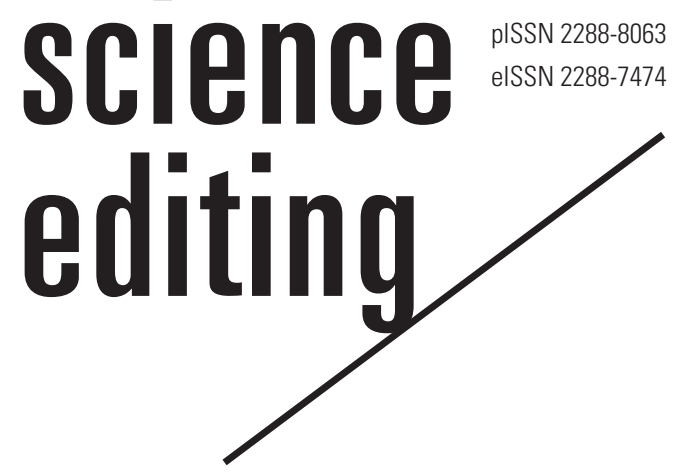

\title{
Increased number of Scopus articles from Indonesia from 1945 to 2020, an analysis of international collaboration, and a comparison with other ASEAN countries from 2016 to 2020
}

\author{
Prakoso Bhairawa Putera ${ }^{1,2}$, Suryanto Suryanto ${ }^{1}$, Sinta Ningrum', Ida Widianingsih", \\ Yan Rianto ${ }^{2}$ \\ ${ }^{1}$ Faculty of Social and Political Sciences, Universitas Padjadjaran, Bandung, Jawa Barat; ${ }^{2}$ Badan Riset dan Inovasi Nasional \\ Republik Indonesia, Jakarta, Indonesia
}

\section{Introduction}

Background: The government of the Republic of Indonesia has set a target for the international publication of 31,159 papers in 2024, according to the 2020-2024 National Medium-Term Development Plan [1], since international publications are acknowledged as an indicator of increased productivity and competitiveness in the field of science and technology. In addition, in the 2017-2045 National Research Master Plan, the Indonesian government has set a productivity target for 2,045 of 22 reputable international scientific publications for every 100 science and technology human resources [2]. Thus, the Indonesian government has implemented reputable international scientific publications as an output indicator for this policy.

This choice was based on the consideration that an increasing number of reputable interna-

Received: November 21, 2021 Accepted: December 29, 2021

\section{Correspondence to}

Prakoso Bhairawa Putera prakoso19001@mail.unpad.ac.id

ORCID

Prakoso Bhairawa Putera https://orcid.org/0000-0002-1474-6028 Suryanto Suryanto

https://orcid.org/0000-0002-7808-5695 Sinta Ningrum

https://orcid.org/0000-0002-5934-9851 Ida Widianingsih

https://orcid.org/0000-0003-2472-5236

Yan Rianto

https://orcid.org/0000-0001-6056-6741 tional scientific publications reflects the ability to create science and technology-based inventions as the upstream facilitators of innovative products with high economic value. This view is also in accordance with previous research results pointing out that the "Circular No. 08 " policy in Vietnam has played an essential role in accelerating the productivity of scientists in the country by generating an increasing number of international publications [3]. In addition, the formation of international collaborations in Iran has been acknowledged based on its international publications [4].

Objectives: This essay aimed to explore the research output of Indonesian researchers in international publications from 1945 to 2020, with a particular focus on international collaborations of Indonesian authors. A comparison was also conducted using data from five other Association of Southeast Asian Nations (ASEAN) countries (Singapore, Malaysia, Thailand, the Philippines, and Vietnam) from 2016 to 2020. 


\section{Data Sources and Queries}

This study utilized data from the Scopus database, accessed on November 25, 2021. Furthermore, to enrich the analysis, comparisons were conducted with data from Singapore, Malaysia, Thailand, the Philippines, and Vietnam. To identify research output from a country, the following query was used (with Indonesia as an example): (AFFILCOUNTRY("Indonesia") AND PUBYEAR > 2015 AND PUBYEAR <2021) (Suppl. 1). Raw data from the search are available in Dataset 1.

\section{International publication trends from Indonesia from} 1945 to 2020

The search results demonstrated that authors with Indonesian affiliations since independence (1945) have generated 217,974 publications in Scopus (Fig. 1), comprising 160 publication sources. Since 2005, Indonesia's international publications have annually experienced significant increases of $10 \%$ to $40 \%$ on average. Of particular note, 2020 had 50,868 publications, reflecting a dramatic increase from the previous year (2015), which had 8,577 publications. Indonesia recorded a significant increase in international publications in the 2016 to 2020 period, with 167,707 publications, corresponding to $584 \%$ increase compared to the previous 5-year period (20112015), which had 28,703 publications.

An analysis according to the subject area found that engineering was the field in which researchers with Indonesian affiliations were most prolific during 1945 to 2020, with 55,604 publications (Fig. 2), followed by physics and astrono- my (38,936 publications), computer science $(36,228$ publications), environmental science (34,999 publications) and social sciences $(26,067$ publications).

The distribution of the subject areas of international publications from Indonesia was analyzed (Table 1 ). The early period (1945-1964) was dominated by publications in fields including agricultural and biological sciences, chemistry, and medicine. In particular, medicine dominated international publications from Indonesia for 5 decades (1955-2004), while engineering dominated Indonesian international publications in 2005 to 2020. This finding indicates that areas such as medicine, agricultural and biological sciences, engineering, and physics and astronomy have become the focus of Indonesian researchers' attention from independence to the present day. The social sciences have also received considerable attention, as shown by their presence among the top five fields of Indonesian international publications in the periods of 1965 to 1994 and 2005 to 2014.

Throughout 1945 to 2020, authors from Indonesia have collaborated with authors from 159 countries. The top $10 \mathrm{col}-$ laborating countries (Fig. 3) were predominated by Asian countries (Japan, Malaysia, Thailand, and South Korea). Indonesian authors have most frequently collaborated in publishing international scientific articles with authors from Japan (12,902 articles), Malaysia (11,363 articles), and Australia (8,021 articles).

Indonesia in comparison with other ASEAN countries In comparison with other ASEAN countries (Singapore, Ma-

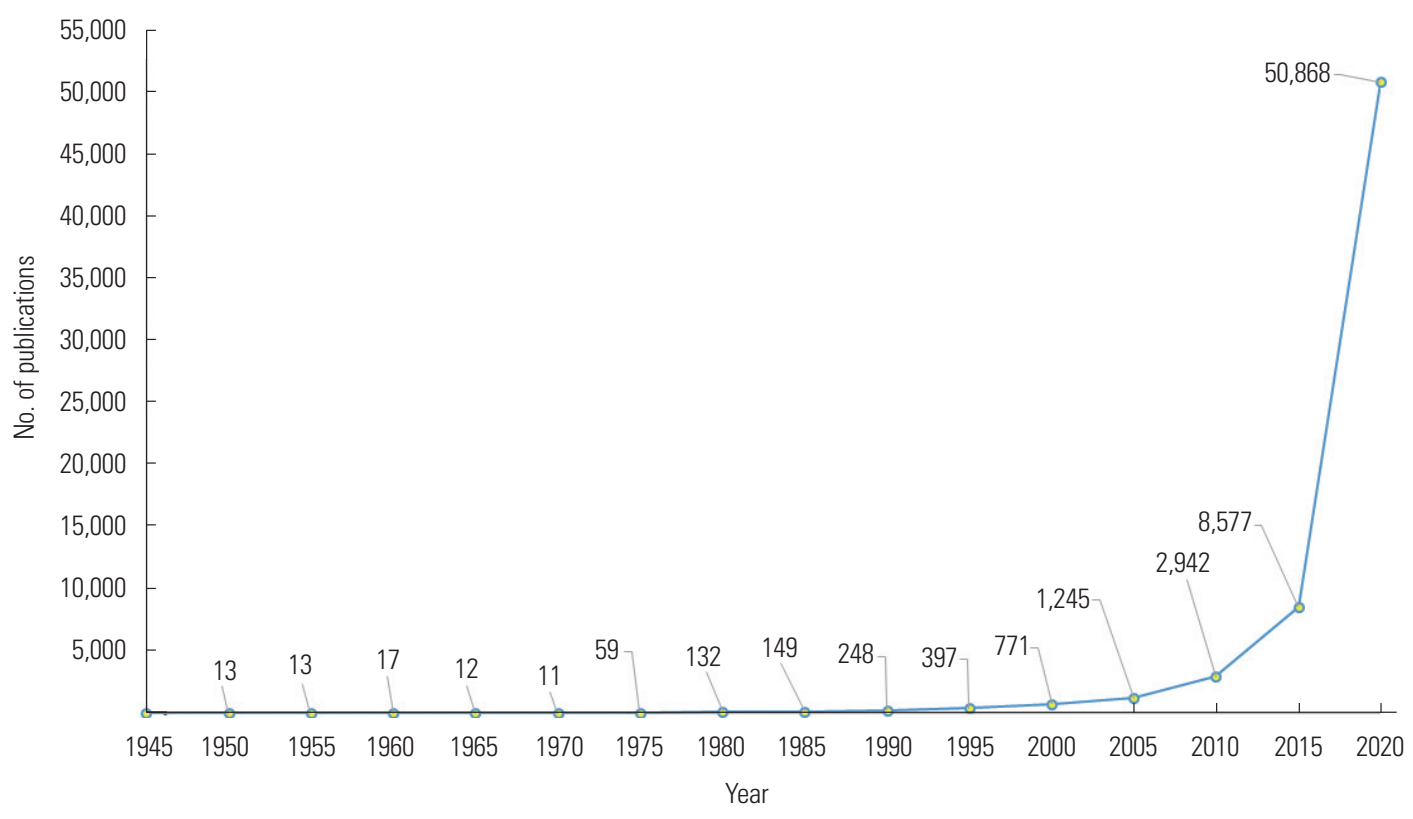

Fig. 1. Indonesian international publication trends in 1945 to 2020. 


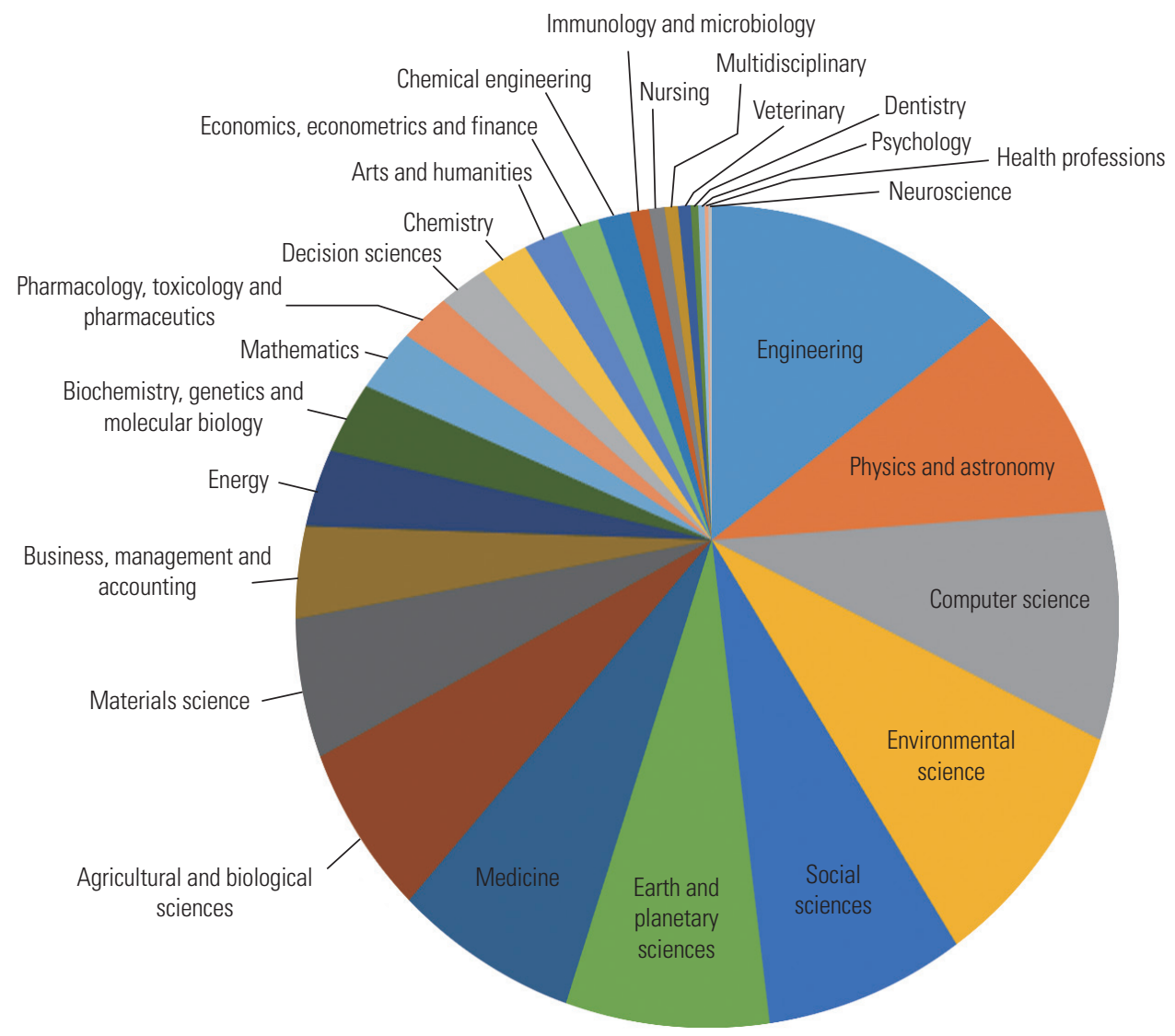

Fig. 2. Distribution of subjects of international publications from Indonesia from 1945 to 2020.

Table 1. The evolution of international publications from Indonesia from 1945 to 2020 by subject area

\begin{tabular}{|c|c|c|c|c|c|c|c|}
\hline 1945-1954 & 1955-1964 & 1965-1974 & 1975-1984 & 1985-1994 & 1995-2004 & 2005-2014 & $2015-2020$ \\
\hline $\begin{array}{l}\text { Agricultural and } \\
\text { biological } \\
\text { sciences; } \\
\text { chemistry; } \\
\text { medicine; } \\
\text { neuroscience; } \\
\text { biochemistry, } \\
\text { genetics and } \\
\text { molecular } \\
\text { biology }\end{array}$ & $\begin{array}{l}\text { Medicine; } \\
\text { biochemistry, } \\
\text { genetics and } \\
\text { molecular } \\
\text { biology; } \\
\text { chemistry; } \\
\text { agricultural and } \\
\text { biological } \\
\text { sciences; } \\
\text { engineering }\end{array}$ & $\begin{array}{l}\text { Medicine; physics } \\
\text { and astronomy; } \\
\text { engineering; } \\
\text { energy; social } \\
\text { sciences }\end{array}$ & $\begin{array}{l}\text { Medicine; } \\
\text { agricultural and } \\
\text { biological } \\
\text { sciences; earth } \\
\text { and planetary } \\
\text { sciences; } \\
\text { environmental } \\
\text { science; social } \\
\text { sciences }\end{array}$ & $\begin{array}{l}\text { Medicine; } \\
\text { agricultural and } \\
\text { biological } \\
\text { sciences; earth } \\
\text { and planetary } \\
\text { sciences; } \\
\text { environmental } \\
\text { science; social } \\
\text { sciences }\end{array}$ & $\begin{array}{l}\text { Medicine; } \\
\text { agricultural and } \\
\text { biological } \\
\text { sciences; } \\
\text { engineering; } \\
\text { biochemistry, } \\
\text { genetics and } \\
\text { molecular } \\
\text { biology; } \\
\text { environmental } \\
\text { science }\end{array}$ & $\begin{array}{l}\text { Engineering; } \\
\text { agricultural and } \\
\text { biological } \\
\text { sciences; } \\
\text { computer } \\
\text { science; } \\
\text { medicine; social } \\
\text { sciences }\end{array}$ & $\begin{array}{l}\text { Engineering; } \\
\text { physics and } \\
\text { astronomy; } \\
\text { computer } \\
\text { science; } \\
\text { environmental } \\
\text { science; earth } \\
\text { and planetary } \\
\text { sciences }\end{array}$ \\
\hline
\end{tabular}

laysia, Thailand, the Philippines, and Vietnam), Indonesia showed a striking trend of increasing publications in the 2016 to 2020 period. In 2019 and 2020, Indonesia led ASEAN countries in the number of publications (Fig. 4).

When comparing the subject areas of Indonesia's international publications to the other five ASEAN countries (Table 2 ), it was noted that the engineering field predominated among publications from Indonesia in the 2016 to 2020 peri- od, as well as in Malaysia, Singapore, Vietnam, and the Philippines. Meanwhile, in Thailand during that period, the subject area of medicine was predominant and engineering ranked in second place. Thus, these findings indicate that in the 2016 to 2020 period, researchers in these six ASEAN countries published more papers in the engineering field than in other subjects.

Japan, Australia, the USA, and the UK were the most com- 


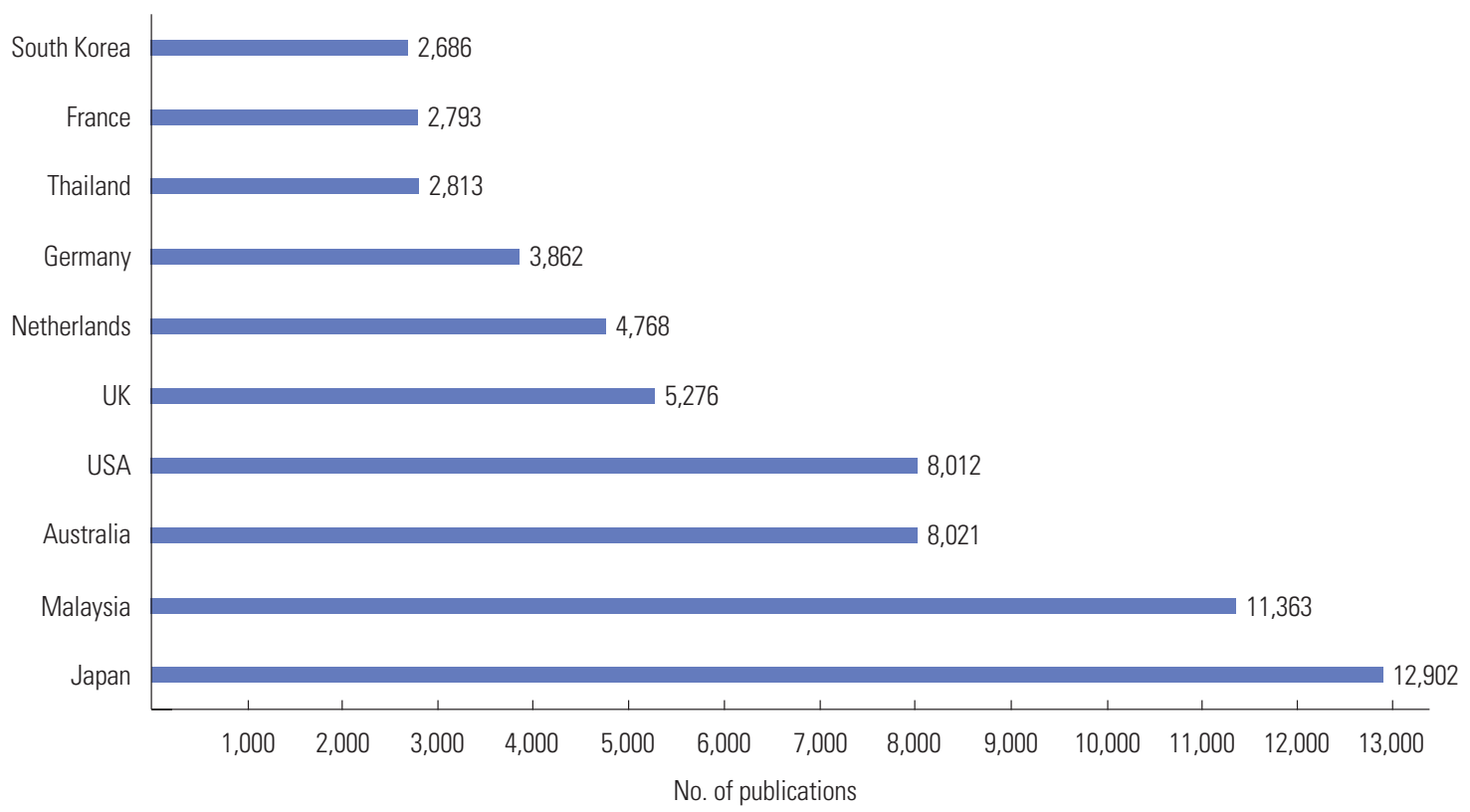

Fig. 3. Top 10 collaborating countries with Indonesian authors from 1945 to 2020.

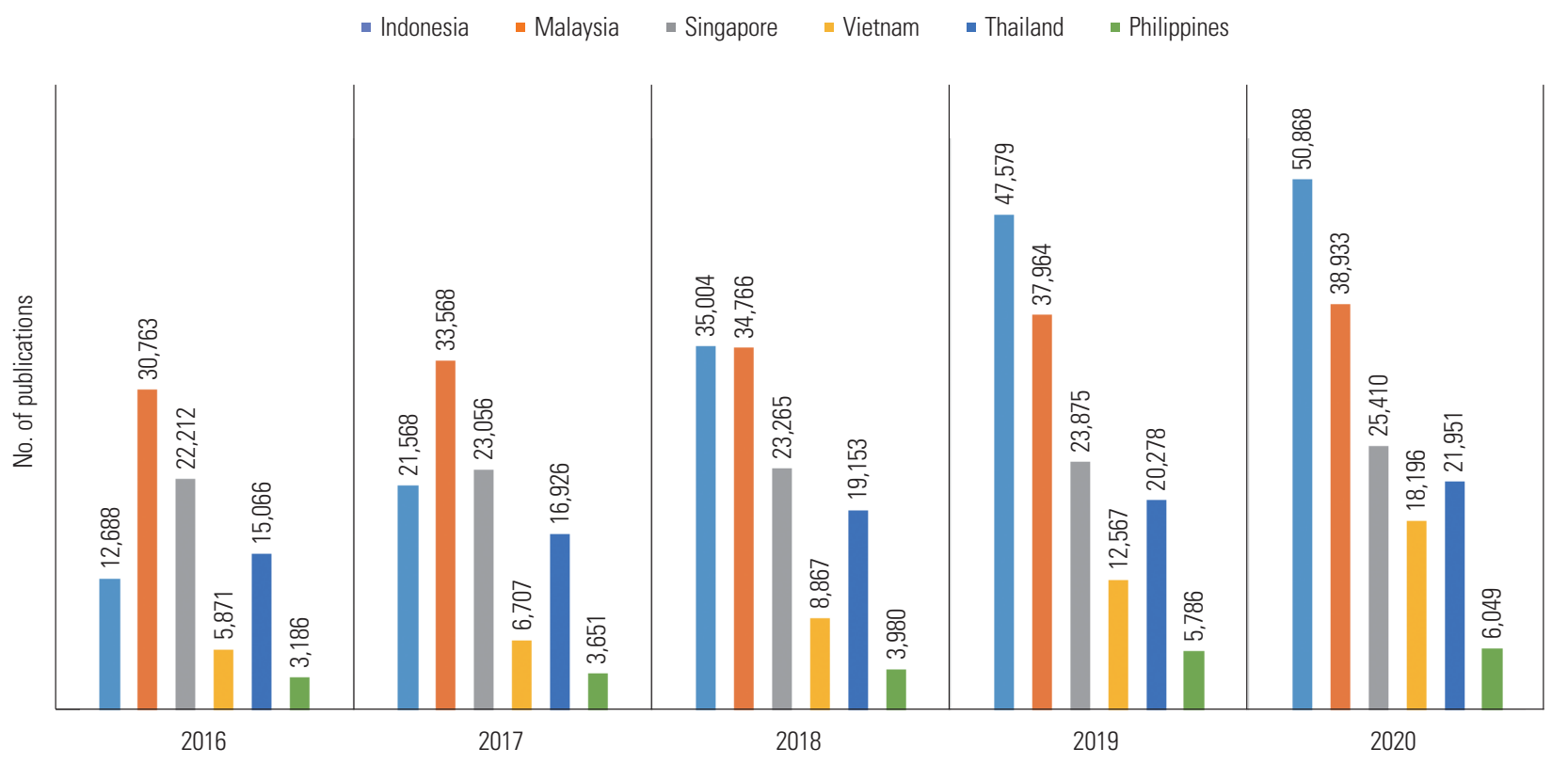

Fig. 4. Comparison of Indonesia's international publications with those of other ASEAN (Association of Southeast Asian Nations) countries from 2016 to 2020.

mon collaborating countries for the publication of international scientific articles with researchers from the six ASEAN countries, including Indonesia (Table 3). The USA was the most common country of collaboration with authors from Vietnam, Thailand, and the Philippines. Meanwhile, authors from Indonesia mainly collaborated with authors from Malaysia and Japan. Authors from Singapore mainly collaborated with authors from China and the USA. Furthermore, authors with Malaysian affiliations also tended to collaborate with authors from the UK and Australia.

The number of Indonesian authors collaborating with authors from Japan in the 2016-2020 period was relatively reasonable, as indicated by the funding sponsorship for published articles, many of which reported receiving funding 
Table 2. Top 10 subject areas of Indonesian international publications compared to those of other ASEAN countries from 2016 to 2020

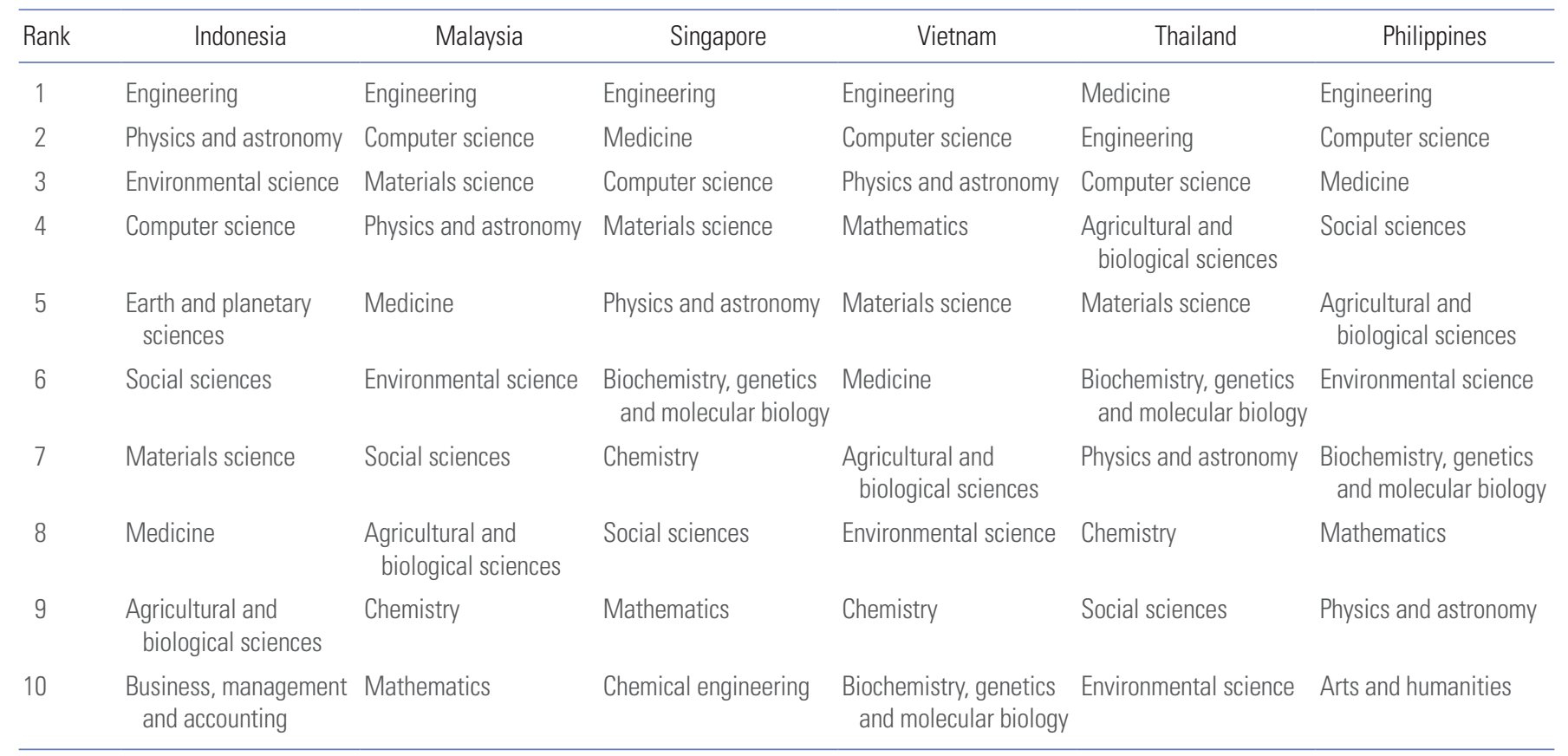

ASEAN, Association of Southeast Asian Nations.

Table 3. Comparison of the top 10 collaborating countries with Indonesian authors in international publications among the six ASEAN countries from 2016 to 2020

\begin{tabular}{|c|c|c|c|c|c|c|}
\hline Rank & Indonesia & Malaysia & Singapore & Vietnam & Thailand & Philippines \\
\hline 2 & Japan & Australia & USA & Japan & Japan & Japan \\
\hline 3 & Australia & Indonesia & UK & South Korea & UK & Australia \\
\hline 4 & USA & USA & Australia & Australia & China & China \\
\hline 7 & Germany & Pakistan & Japan & UK & France & Germany \\
\hline 8 & Taiwan & Saudi Arabia & Canada & Germany & Germany & Malaysia \\
\hline 9 & South Korea & Japan & Hong Kong & Iran & Malaysia & South Korea \\
\hline 10 & Thailand & Iran & France & India & South Korea & India \\
\hline
\end{tabular}

ASEAN, Association of Southeast Asian Nations.

from Japan Society for the Promotion of Science (1,783 articles) and the Japanese Ministry of Education, Culture, Sports, Science and Technology (1,478 articles). A similar pattern occurred in authors from Singapore collaborating with authors from China from 2016 to 2020, which corresponded to funding sponsorship from the National Natural Science Foundation of China (13,823 articles), Ministry of Education of the People's Republic of China (1,909 articles), Ministry of Science and Technology of the People's Republic of China (1,193 arti- cles), and the China Scholarship Council with 1,321 articles.

\section{Indonesian Government's Policy to Encourage International Publications}

The significant increase in Indonesia's international publications has been a direct consequence of national policy, particularly the National Standards for Higher Education, which have been stipulated since 2015 through the Regulation of the 
Ministry of Research, Technology and Higher Education Number 44 of 2015, and further updated through the Regulation of the Ministry of Education and Culture Number 3 of 2020. In addition, Law Number 12 of 2012, regarding higher education, stipulates in article 12 paragraphs 2 and 3 that a lecturer serving as a scientist is mandated to develop and disseminate science and/or technology through scientific reasoning and research. Lecturers are also required to publish scientific publications as a source of learning. In fact, since January 27, 2012, there has been a provision for graduates of doctoral programs to produce papers accepted for publication in international journals. This provision is contained in the Circular Letter of the Director General of Higher Education, Ministry of Education and Culture, Number 152/E/T/2012 (Concerning the Publication of Scientific Work). Furthermore, policies concerning international publications in functional research positions are stipulated through the Ministry of State Apparatus Empowerment and Bureaucratic Reform Regulation Number 34 of 2018.

The obligation of international publications in Indonesia is actualized through a number of regulations implemented by the government through various acceleration programs, with publication incentives such as (1) incentives for articles in international scientific journals since 2014, by providing incentives for 125 lecturers/researchers in 2017 whose scientific articles have been published in international journals, with a maximum incentive of 35,000,000 Indonesian rupiah (approximately 2,500 US dollars). This program is implemented by the Directorate General of Research and Development, at the Ministry of Research, Technology and Higher Education [5]. (2) The 2020 Scientific Journal Quality Improvement Incentive Program, organized by the Ministry of Research and Technology/National Research and Innovation Agency, aims to encourage the publication of scientific journals in order to improve journal quality and to help journals become internationally reputable [6]. This program is in accordance with the obligations of journal accreditation in Indonesia [7]. (3) In addition, there are other incentives for international publications at the university level in Indonesia $[8,9]$.

\section{Conclusion}

Researchers from Indonesia have published 217,974 international publications from 1945 to 2020 in the Scopus database. The quantity of publications has increased in the eight decades since the independence of the Republic of Indonesia. In 2019 and 2020, Indonesia had the highest number of publications among ASEAN countries. Subject areas including medicine, agricultural and biological sciences, engineering, and physics and astronomy have been the most dominant fields in publications by researchers from Indonesia in international journals. Researchers from Indonesia have collaborated with authors from 159 countries, which are predominated by Asian countries (Japan, Malaysia, Thailand, and South Korea). Indonesia's international publications have also been influenced by funding sponsorship from Japan, as evidenced by the Japan Society for the Promotion of Science, the Ministry of Education, Culture, Sports, Science and Technology, the Japan Science and Technology Agency, the Japan Agency for Medical Research and Development, and the Japan International Cooperation Agency, which provided financial support for 3,793 publications during the 2016 to 2020 period. In 2020, authors from Indonesia were able to publish 50,868 publications in the Scopus database. The target set by the government of Indonesia in the National Medium-Term Development Plan 2020-2024 to achieve 31,159 international publications in 2024 should be updated to reflect these circumstances.

\section{Conflict of Interest}

No potential conflict of interest relevant to this article was reported.

\section{Funding}

The authors received no financial support for this study.

\section{Data Availability}

Dataset file is available from the Harvard Dataverse at: https:// doi.org/10.7910/DVN/ISWZXH

Dataset 1. Search results according to search terms including country, year, and subject areas in Scopus

\section{Supplementary Material}

Supplementary file is available from the Harvard Dataverse at: https://doi.org/10.7910/DVN/ISWZXH

Suppl. 1. Query terms

\section{References}

1. Cabinet Secretariat of the Republic of Indonesia. Appendix 1. Narrative of the Presidential Regulation of the Republic of Indonesia Number 18 of 2020 Concerning the 2020-2024 National Mid-Term Development Plan. Jakarta: Cabinet Secretariat of the Republic of Indonesia; 2020.

2. Cabinet Secretariat of the Republic of Indonesia. Presiden- 


\section{science editing}

tial Regulation of the Republic of Indonesia Number 38 of 2018 Concerning the 2017-2045 National Research Master Plan. Jakarta: Cabinet Secretariat of the Republic of Indonesia; 2018.

3. Phan Thi TT, Pham HH, Nguyen HL, Nguyen LC. International academic publishing in Vietnam: policy efficiency and room for development. Sci Ed 2021;8:162-5. https:// doi.org/10.6087/kcse.249

4. Hayati Z, Didegah F. International scientific collaboration among Iranian researchers during 1998-2007. Libr Hi Tech 2010;28:433-46. https://doi.org/10.1108/07378831011076675

5. Directorate General of Research and Development Strengthening. Incentive program for scientific articles [Internet]. Jakarta: Ministry of Research, Technology and Higher Education; 2016 [cited 2021 Dec 12]. Available from: https:// lldikti12.ristekdikti.go.id/2016/04/15/insentif-article-padajurnal-internasional-tahun-2016.html

6. Directorate of Intellectual Property Management, Deputy for Research and Development Strengthening. Scientific journal quality improvement incentive program in 2020 [Internet]. Jakarta: Ministry of Research and Technology; National Agency for Research and Innovation; 2020 [cited 2021 Dec 12]. Available from: https://insentifki.ristekbrin. go.id/informasi

7. Putera PB, Suryanto S, Ningrum S, Widianingsih I, Rianto Y. Policies of scholarly journal accreditation in Indonesia. Sci Ed 2021;8:166-71. https://doi.org/10.6087/kcse.250

8. Directorate of Research and Development, Universitas Indonesia. Scientific publication incentive guide 2016 [Internet]. Depok: Universitas Indonesia; 2016 [cited 2021 Dec 12]. Available from: https://research.ui.ac.id/research/pengumuman/panduan-insentif-publikasi-ilmiah-2016/

9. Hendriyana A. Pursuing internationalization acceleration, unpad prepares world class university grants [Internet]. Bandung: Universitas Padjadjaran; 2021 [cited 2021 Dec 12]. Available from: https://www.unpad.ac.id/2021/07/kejar-akselerasi-internasionalisasi-unpad-siapkan-hibahworld-class-university/ 